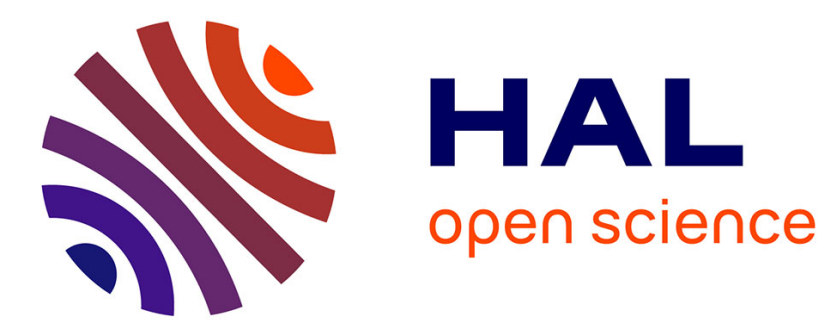

\title{
Restricted bovine serum albumin diffusion through the protein network of pasta
}

\author{
Anthony Fardet, Christine C. Hoebler, G. Djelveh, J.L. Barry
}

\section{To cite this version:}

Anthony Fardet, Christine C. Hoebler, G. Djelveh, J.L. Barry. Restricted bovine serum albumin diffusion through the protein network of pasta. Journal of Agricultural and Food Chemistry, 1998, 46 (11), pp.4635-4641. hal-02687424

\section{HAL Id: hal-02687424 https://hal.inrae.fr/hal-02687424}

Submitted on 1 Jun 2020

HAL is a multi-disciplinary open access archive for the deposit and dissemination of scientific research documents, whether they are published or not. The documents may come from teaching and research institutions in France or abroad, or from public or private research centers.
L'archive ouverte pluridisciplinaire HAL, est destinée au dépôt et à la diffusion de documents scientifiques de niveau recherche, publiés ou non, émanant des établissements d'enseignement et de recherche français ou étrangers, des laboratoires publics ou privés. 


\section{Restricted Bovine Serum Albumin Diffusion through the Protein Network of Pasta}

Anthony Fardet, Christine Hoebler, Gholamreza Djelveh, and Jean-Luc Barry

Laboratoire des Fonctions Digestives et de Nutrition Humaine, Institut National de la Recherche Agronomique, B.P. 71627, 44316 Nantes Cédex 03, France, and Laboratoire de Génie Chimique Biologique, Faculté des Sciences Blaise-Pascal, 24 Avenue des Landais, 63177 Aubière Cédex, France

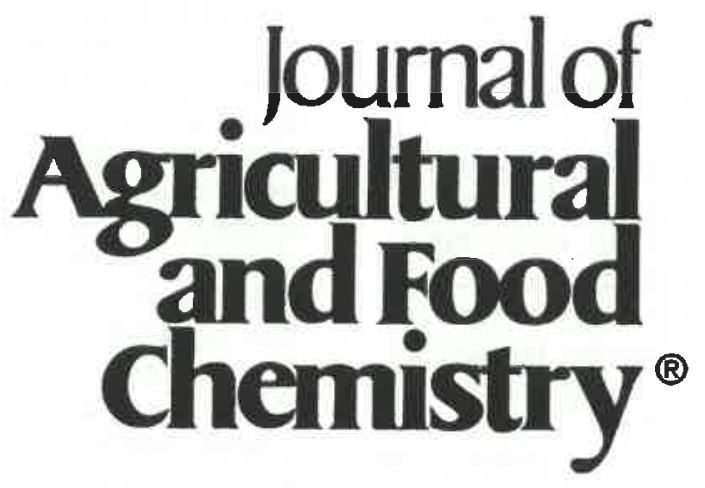

Reprinted from

Volume 46, Number 11, Pages 4635-4641 


\title{
Restricted Bovine Serum Albumin Diffusion through the Protein Network of Pasta
}

\author{
Anthony Fardet, ${ }^{\dagger}$ Christine Hoebler, ${ }^{*}{ }^{\dagger}$ Gholamreza Djelveh, ${ }^{\ddagger}$ and Jean-Luc Barry ${ }^{\dagger}$
}

\begin{abstract}
Laboratoire des Fonctions Digestives et de Nutrition Humaine, Institut National de la Recherche Agronomique, B.P. 71627, 44316 Nantes Cédex 03, France, and Laboratoire de Génie Chimique Biologique, Faculté des Sciences Blaise-Pascal, 24 Avenue des Landais, 63177 Aubière Cédex, France
\end{abstract}

\begin{abstract}
Food digestion may be influenced by the diffusion processes that govern the accessibility of substrates to enzymes, both within the intestinal lumen and within the food structure itself. The purpose of this study was to determine the diffusion coefficient $(D)$ of bovine serum albumin (BSA), which simulates $\alpha$-amylase diffusional behavior, in the pasta protein network. A diffusion cell consisting of two well-stirred compartments separated by a lasagne matrix was designed and used. Starch was enzymatically removed from the lasagne, and ${ }^{14} \mathrm{C}-\mathrm{BSA}$ was allowed to diffuse through the protein matrix for $26 \mathrm{~h}$. The $D$ obtained was $\sim 2$-fold lower than the self-diffusion coefficient of BSA in free solvent. Protein network tortuosity, which increases path length diffusion, was probably the main factor involved in this restricted diffusion process. The presence of emulsified lipid, which is partly representative of the digestive environment, did not limit BSA diffusion toward and within the pasta protein network.
\end{abstract}

\section{Keywords: Pasta protein network; diffusion; digestion}

\section{INTRODUCTION}

It is generally considered that foodstuffs, after their passage through the stomach, are emptied in the form of chyme and not as particles with an intact physical structure. However, from the mouth to the large intestine, some foodstuffs or fiber may retain a complex solid structure (Noah et al., 1998; Hoebler et al., 1997). Enzyme diffusion processes in food structure (in the upper digestive tract) or fiber (at the colonic level) appear to be a key factor determining the rate at which macromolecules are degraded into nutrients. Although the diffusivity of solute through model foods has been exhaustively studied for biotechnological purposes, for example, the diffusion of $\mathrm{NaCl}$ through cheese (Zorrilla and Rubiolo, 1994) and agar gel (Djelveh et al., 1989) or of bovine serum albumin (BSA) (which simulates $\alpha$-amylase) through starch gels (Leloup et al., 1990), no studies to date have investigated the influence of complex food structure on enzyme diffusion in the digestive process.

Enzyme penetration/diffusion into food is determined mainly by physicochemical factors such as the tortuosity, porosity, and crystallinity of food components. Among these factors, porosity has been most studied, especially in the case of fiber. It has been shown in vitro that the hydrolysis of cellulosic material is strongly related to the available pores for diffusion of cellulase (Wong et al., 1988; Tanaka et al., 1988). It is also now well-established that the increase of fiber porosity by technological processes or in vitro digestion increases

* Author to whom correspondence should be addressed (telephone +3324067 50 23; fax +332406750 12; e-mail hoebler@inra.nantes.fr).

$\dagger$ Institut National de la Recherche Agronomique.

₹ Laboratoire de Génie Chimique Biologique. the initial rate of in vitro fermentation by bacterial enzymes (Guillon et al., 1992; Auffret et al., 1993; Fardet et al., 1997). In the case of complex foodstuffs, very few studies have tried to relate the porosity of food structure to its digestion, although one technological study has shown that the fine structure of the processed rice food matrix (normally cooked, autoclaved, and retrograded), especially the pore size distribution, was correlated with in vitro starch digestibility (Ito et al., 1988).

Porosity depends mainly on food texture, as determined by technological processes. For example, the different textures of bread and pasta affect the rate of starch degradation in vitro and in vivo: Because of the loose texture of bread, starch is rapidly degraded, whereas the compact texture of pasta restricts the access of $\alpha$-amylase to starch (Granfeldt and Björck, 1991; Karinthi, 1995). In pasta, the low degree of starch swelling, and especially the presence of a fine and insoluble protein network, may slow starch degradation (Colonna et al., 1990). The mechanisms by which this protein network impairs $\alpha$-amylase action are not wellelucidated. Light and electron microscopy have shown that this network is highly porous and tortuous, with holes in the range of $0.5-40 \mu \mathrm{m}$ (Fardet et al., 1998). The network surrounds the starch granules, but some connections in the walls of the protein network itself $(\sim 0.5-3 \mu \mathrm{m})$ allow access of all the potential degradable starch fractions to $\alpha$-amylase. Thus, the porosity of the protein matrix is not a limiting factor for starch hydrolysis (Fardet et al., 1998).

The main purpose of this study was to test the hypothesis that the geometry of the protein network (i.e., tortuosity) plays a major role in the slow degradation of starch by restricting the diffusion rate of $\alpha$-amylase. The diffusion of radiolabeled methylated BSA 


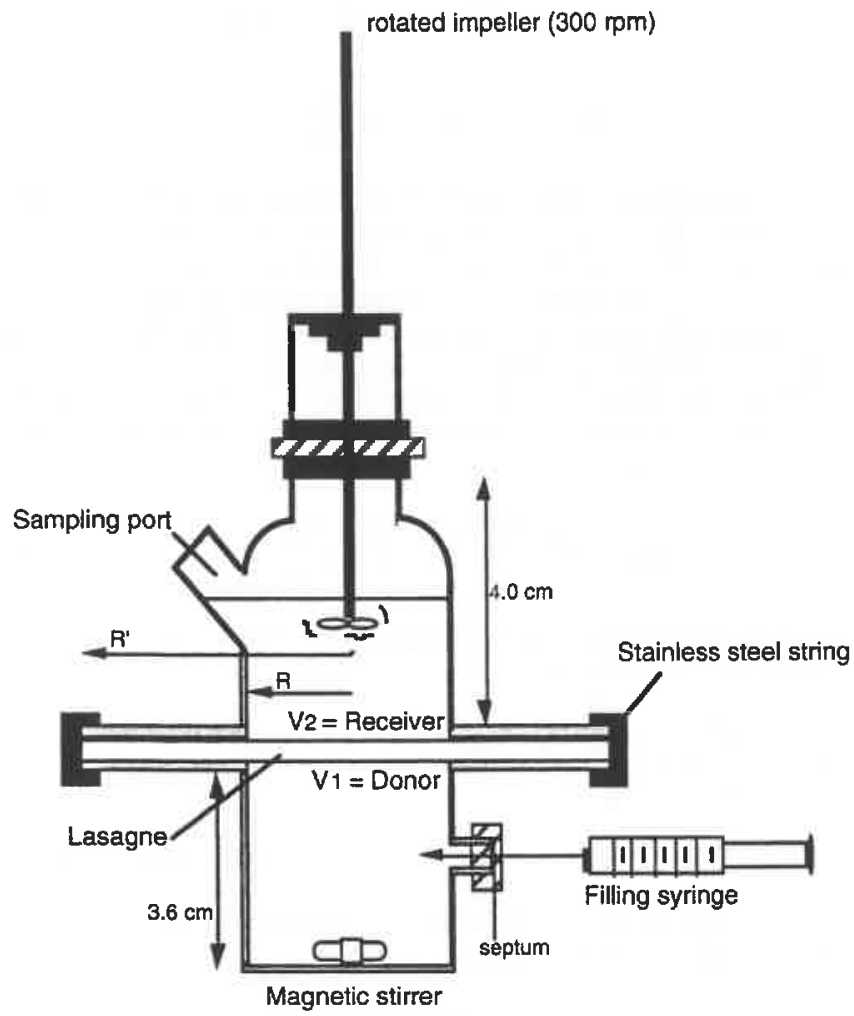

Figure 1. Schematic view of the diffusion cell.

through the protein matrix of lasagne was investigated via the well-known diffusion cell technique (Stokes, 1950), which has recently been improved and applied to gels and model/real foods (Djelveh et al., 1989; Axelsson and Westrin, 1991). BSA was chosen as the probe species because its diffusion behavior, which is comparable to that of $\alpha$-amylase (Leloup et al., 1990, has been extensively characterized (Wagner and Scheraga, 1956; Keller et al., 1971) and because it is a globular protein similar in size to many amylolytic enzymes (Buisson et al., 1987). As foods are rarely eaten alone, and as the digestive environment may influence enzyme diffusion to the food matrix, this study also investigated the influence of a lipid complex emulsion (as found at the duodenal level) on the BSA diffusion coefficient in the pasta protein network.

\section{MATERIALS AND METHODS}

Diffusion Apparatus. Two diffusion cells were used, consisting of two glass compartments with different volumes (cell $1, V_{1} \simeq 41 \mathrm{~mL}$ and $V_{2}=20 \mathrm{~mL}$; cell $2, V_{1} \simeq 37.5 \mathrm{~mL}$ and $V_{2}=20 \mathrm{~mL}$; Figure 1). The radius of the effective aperture $R$ was either $2.0 \mathrm{~cm}$ (cell 1) or $1.66 \mathrm{~cm}$ (cell 2). The outer radius of the diaphragm holder $R^{\prime}$ was constant and equal to $5 \mathrm{~cm}$. The liquids in the upper and lower compartments were stirred by a turbine impeller rotated by a motor and a magnetic stirrer, respectively. The two compartments were separated by a slice of cooked lasagne. The diffusion cells were suspended in a thermostated water bath (accuracy $\pm 0.1^{\circ} \mathrm{C}$ ). All diffusion measurements were done at $37^{\circ} \mathrm{C}$.

Preparation of the Pasta Protein Diaphragm. Lasagnes were prepared in the Cereal Technology Laboratory of the INRA (Montpellier, France) from a mixture of $78.4 \%$ (w/ w) semolina (3SE durum wheat white semolina; $70 \%$ extraction; provided by the Semoulerie of Normandie) and $21.6 \%$ water (final moisture content $=33.5 \%$ ). These ingredients were blended for $20 \mathrm{~min}$ at $120 \mathrm{rpm}$ and placed under vacuum. Extrusion was performed at $40^{\circ} \mathrm{C}$ under $136-161 \mathrm{~Pa}$. Lasa- gnes were desiccated at $55^{\circ} \mathrm{C}$ for $17 \mathrm{~h}$ to a final moisture content of $\sim 12 \%$ and then cooked in excess boiling mineral water (Evian) containing $7 \mathrm{~g} / \mathrm{L} \mathrm{NaCl}$. The cooking time ( $7 \mathrm{~min}$ ) was determined to be optimal when complete starch gelatinization had occurred according to French standards (NF ISO 7304).

The lower compartment of the diffusion cell was filled with a solution containing human salivary $\alpha$-amylase $(0.15 \mu \mathrm{kat} /$ $\mathrm{mL}$ supplied by Sigma; EC 1.2.1.1.; specific activity $=1 \mu \mathrm{kat} /$ $\mathrm{mg}$ of dry matter) in a $5 \mathrm{mM}$ phosphate buffer ( $\mathrm{pH}$ 6.9-7.0) with $0.25 \mathrm{mM} \mathrm{CaCl}_{2}, 1.75 \mathrm{mM} \mathrm{NaCl}$, and $0.02 \%$ sodium azide $(w / v)$. The lasagne was carefully placed on the lower part of the diaphragm holder to ensure that no air bubbles were introduced between the lasagne and the enzymatic solution. The upper part of the diaphragm holder was fastened with a steel string tightened by means of a screw mounted on the string. The upper compartment was then filled with enzymatic solution. Before the experiment, the diffusion cell was placed in a thermostated water bath so that the level of enzymatic solution in the upper compartment was below that of the water. The thermostated water bath was placed on a magnetic stirring device.

To remove residual $\alpha$-amylase activity and hydrolyzed starch fractions trapped in the protein matrix, enzymatic solutions from both compartments were replaced by $5 \mathrm{mM}$ phosphate buffer. Washing efficiency was controlled by measuring $\alpha$-amylase activity regularly [Phadebas test procedure described by Leclerc et al. (1993)] and the amount of $\alpha$-glucans released (Tollier and Robin, 1979) in the upper compartment of the diffusion cell within $26 \mathrm{~h}$ of washing. The release of glucose and $\alpha$-amylase activity reached a plateau within $\sim 5$ $\mathrm{h}$. The protein matrix was washed for $14 \mathrm{~h}$ at $37^{\circ} \mathrm{C}$ to ensure maximum efficiency of release.

Characterization of the Lasagne Protein Diaphragm. Total starch and resistant starch contents of cooked lasagnes, before and after starch removal, were determined according to the method of Champ et al. (1995). Protein content was determined according to Kjeldahl's method.

The molecular weights of the linear $\alpha$-glucans recovered after starch hydrolysis and washing of the lasagne protein network were studied by size exclusion chromatography (SEC) performed on a Superose 12TM column (Pharmacia, $30 \mathrm{~cm}$ long, $1 \mathrm{~cm}$ diameter). Dried samples, obtained after freezedrying and grinding of the lasagne protein network (50-100 $\mathrm{mg}$ ), were solubilized for $24 \mathrm{~h}$ in $1 \mathrm{~N} \mathrm{KOH}$ under mixing, diluted with water to $0.1 \mathrm{~N} \mathrm{KOH}$, and centrifuged $(10000 \mathrm{~g}$ for $10 \mathrm{~min}$ ) to remove most of the gluten proteins. Samples (100 $\mu \mathrm{L}$ ) were injected into the column after filtration through a Millipore filter $(0.45 \mu \mathrm{m})$ and eluted by $0.1 \mathrm{~N} \mathrm{KOH}(20 \mathrm{~mL} / \mathrm{h})$. Each fraction was then analyzed for total glucose determination by the miniaturized D-glucose oxidase-peroxidase method (Thivend et al., 1972) and identified by its partition coefficient $K_{\text {av }}$

$$
K_{\mathrm{av}}=\left(V_{\mathrm{e}}-V_{0}\right) /\left(V_{\mathrm{t}}-V_{0}\right)
$$

where $V_{e}, V_{0}$, and $V_{t}$ are, respectively, the fraction elution volume, exclusion volume (as native elution volume), and total volume (as glucose elution volume). The calibration was carried out with lintnerized potato starch (prepared locally). The plotting of log average chain length (DP) versus $K_{\mathrm{av}}$ gave a linear regression between the two variables from which the calibration curve (over the range of $K_{\mathrm{av}}$ from 0.40 to 0.93 ) was obtained:

$$
\log (\mathrm{DP})=3.915-3.701 K_{\mathrm{av}}
$$

Thus, each eluted peak was defined by the degree of polymerization (DP) at its maximal concentration. Results are the means of duplicates.

Confocal laser scanning microscopy (CLSM; Zeiss LSM 410, Carl Zeiss, Germany) was used to examine the overall organization and three-dimensional structure of the protein network of lasagne inside the food structure before and after starch 
hydrolysis. Bulk sections $\sim 500 \mu \mathrm{m}$ thick were stained for $2 \mathrm{~h}$ within a $0.01 \%(\mathrm{w} / \mathrm{v})$ fuchsin acid solution diluted in acetic acid 1\% (v/v) (ref A 3908; Sigma, St. Louis, MO). Sections were then washed overnight at $4^{\circ} \mathrm{C}$. Several sections were mounted in distilled water onto cavity slides. A coverslip was added and the preparation sealed with nail varnish to prevent drying. Bulk samples were examined in the epi-fluorescence mode of the microscope. Samples were excited by a green laser beam at $543 \mathrm{~nm}$, and the emitted light was selected by a long pass filter $(>570 \mathrm{~nm})$. The laser beam focused on an $\sim 2 \mu \mathrm{m}$ thick plane inside the sample. A sequence of 12 images, each taken $2 \mu \mathrm{m}$ higher in the sample, allowed the three-dimensional structure of the lasagne protein matrix to be reconstructed on a PC computer. Because of the false color scale ( 8 bit grayscale) in the images, the pasta protein network appeared white in the micrographs.

Diffusion Measurements. Prior to the experiment, solutions and the protein matrix were kept at the experimental temperature to avoid volume changes during diffusion measurements. The phosphate buffer was degassed for $30 \mathrm{~min}$ before being introduced into the two compartments of the diffusion cell. A given volume (from 37.1 to $41.9 \mathrm{~mL}$ according to the diffusion experiment considered) of buffer was introduced into the lower compartment and $20 \mathrm{~mL}$ into the upper one. Radioactive [methyl-14 C]BSA $(20-60 \mu \mathrm{L}, 0.05-0.3 \mu \mathrm{Ci})$ (DuPont NEN, $0.024 \mathrm{mCi} / \mathrm{mg}, 0.005 \mathrm{mCi} / \mathrm{mL}$; MW 69 000) was then injected into the lower compartment by the injection port (Figure 1). Stirring (300 rpm) provided perfect mixing within both compartments and allowed us to neglect the resistance of the boundary layers of the membrane as compared to the resistance within the membrane itself. A $2 \mathrm{~mL}$ receiver compartment sample was taken after $\sim 5$ min to check for any leaks in the apparatus. The diffusion process through the protein network of lasagne was monitored by determining the increase in radioactivity in the initially BSA-free compartment. Samples (2 $\mathrm{mL}$ ) were drawn from the upper compartment at intervals for up to 26-29 $\mathrm{h}$ and replaced by $2 \mathrm{~mL}$ of phosphate buffer at $37^{\circ} \mathrm{C}$ to ensure that total volume remained constant (the dilution effect was considered insignificant). The $2 \mathrm{~mL}$ samples were mixed with $18 \mathrm{~mL}$ of high-flash-point LSC cocktail (Ultima Gold, Packard) and analyzed for radioactivity using a liquid scintillation analyzer (model 2500TR, Tri-Carb). Radioactivity was corrected for quenching, and measurements were repeated three times. A blank containing only phosphate buffer was used, and its radioactivity was subtracted from each aliquot.

After the last sample was withdrawn, the rotated impeller was removed and the entire device dismantled. Exact protein matrix diaphragm thickness $(L)$ was measured with an upright dial gauge. Measurements were made at several points $(n=$ 10) along the surface, and the mean value of diaphragm thickness was calculated. No significant change in mean protein diaphragm thickness was observed before and after diffusion experiments. The mean surface area of the protein matrix was determined by measuring its diaphragm diameter at eight different sites with a slide gauge.

To study the influence of emulsified lipids, diffusion experiments were also performed in the presence of a coarse ( 7.1 $\mu \mathrm{m}$ mean droplet size) enteral lipid complex emulsion (Clintec Technologies Laboratories, Le Plessis Robinson, France) mixed with phosphate buffer $(1.1 \% \mathrm{w} / \mathrm{v})$ in the two compartments of the diffusion cell.

Theoretical Considerations. The model used to determine the diffusion coefficient through the protein matrix was Fick's second law:

$$
D \frac{\partial^{2} C}{\partial x^{2}}=\frac{\partial C}{\partial t}
$$

For the diffusion cell, the appropriate boundary and initial conditions were

$$
t=0 \quad \text { for all } x \quad C=0
$$

$$
\begin{gathered}
x=0 \quad \text { for all } t>\left.0 \quad C\right|_{x=0}=K C_{1} \\
x=L \quad \text { for all } t>0 \quad-\left.A D \frac{\partial C}{\partial x}\right|_{x=L}=V_{2} \frac{\mathrm{d} C_{2}}{\mathrm{~d} t}
\end{gathered}
$$

The partition coefficient $K$ differentiates the solute concentration at the surface of the protein matrix from that in the solution. The third boundary condition indicates that at $x=$ $L$ the solute was immediately transferred from the surface of the foodstuff to the receiver compartment. This condition is valid only when the reservoir is perfectly mixed.

The expression for the change of BSA mass in the upper compartment versus time was obtained by the integration of the following equation:

$$
Q_{2}=\int_{0}^{t} V_{2} \frac{\mathrm{d} C_{2}}{\mathrm{~d} t}=-\left.\int_{0}^{t} A D\left(\frac{\mathrm{d} C}{\mathrm{~d} x}\right)\right|_{x=L} \mathrm{~d} t
$$

The integration procedure is given by Crank (1975), and the resulting equation is

$$
\begin{array}{r}
Q_{2}=2 \frac{V_{2}}{V_{1}} \beta\left(Q_{1}\right) \sum_{0}^{\infty}\left[\left(\alpha_{n}^{2}+\beta^{2}\right) /\left(\alpha_{n}^{2}+\beta^{2}+\beta\right)\right] \frac{\cos \alpha_{n}}{\alpha_{n}^{2}}[1- \\
\left.\exp \left(-D \alpha_{n}^{2} t / L^{2}\right)\right]
\end{array}
$$

In this expression, $\beta=L A K / V_{2}$ is a dimensionless number and $\alpha_{n}$ are the positive roots of

$$
\alpha_{n} \tan \alpha_{n}=\beta
$$

The values of $D$ and $\mathrm{K}$ are determined from the mass of BSA versus the time plot by minimizing squares of the deviation between the observed $\left(Q_{2}\right)_{\exp }$ and the calculated $\left(Q_{2}\right)_{\text {cal }}$ values using eq 6 . The minimum of the criterion

$$
\mathrm{CRIT}=\sum_{i=1}^{N}\left(C_{2, \exp }-C_{2, \mathrm{cal}}\right)^{2}
$$

is obtained by the Gauss-Newton method.

After sufficient time has elapsed, and for small values of $\beta$, the exponential terms, except the first one $(n=0)$ in eq 6 , become zero, and eq 6 is reduced to the following form:

$$
Q_{2}=\frac{A K D}{L}\left(C_{1,0}-C_{2,0}\right) t=\frac{A D_{\mathrm{eff}}}{L}\left(C_{1,0}-C_{2,0}\right) t
$$

This situation occurs when pseudo-steady-state solute flow has been reached in the protein matrix. In that case, the slope of the $Q_{2}$ versus time curve can be used to obtain $K D$, the effective diffusion coefficient, $D_{\text {eff. }}$

\section{RESULTS AND DISCUSSION}

Characterization of the Pasta Protein Matrix. Before diffusion experiments, starch contained in lasagne was hydrolyzed for $24 \mathrm{~h}$ to allow maximum starch degradation (Fardet et al., 1998). The protein matrix was then washed for $\sim 14 \mathrm{~h}$. These two steps were performed within the diffusion cell. Nonetheless, even after $14 \mathrm{~h}$ of washing some starch fractions (16\% of the dry matter content with $49 \%$ of resistant starch, Table 1 ) and $\alpha$-amylase activity (result not shown) remained in the protein matrix of lasagne.

SEC results (Figure 2) indicated that the remaining starch fraction in the lasagne corresponded mainly to hydrolyzed starch residues with maximum DPs at 122 and 52. Only a very small fraction was totally excluded from the column (at $K_{\mathrm{av}}=0$ ). This insignificant starch fraction of high DP (DP > 200) corresponded to large 
Table 1. Chemical Characteristics of Lasagne before and after $\alpha$-Amylolysis with HSA ${ }^{\alpha}$

\begin{tabular}{lccccr}
\hline & $\begin{array}{c}\text { dry } \\
\text { matter (\%) }\end{array}$ & $\begin{array}{c}\text { proteins }^{b} \\
(\%)\end{array}$ & $\begin{array}{c}\text { total } \\
\text { starch }^{b}(\%)\end{array}$ & $\begin{array}{c}\text { resistant } \\
\text { starch }^{b}(\%)\end{array}$ & RS/TS \\
\hline before & 32.2 & 11.7 & 75.0 & 1.0 & 1.4 \\
after & 11.6 & 74.1 & 15.8 & 7.8 & 48.8
\end{tabular}

${ }^{a}$ Human salivary a-amylase. ${ }^{b}$ On a dry-matter basis. ${ }^{c}$ Resistant starch/total starch ratio.

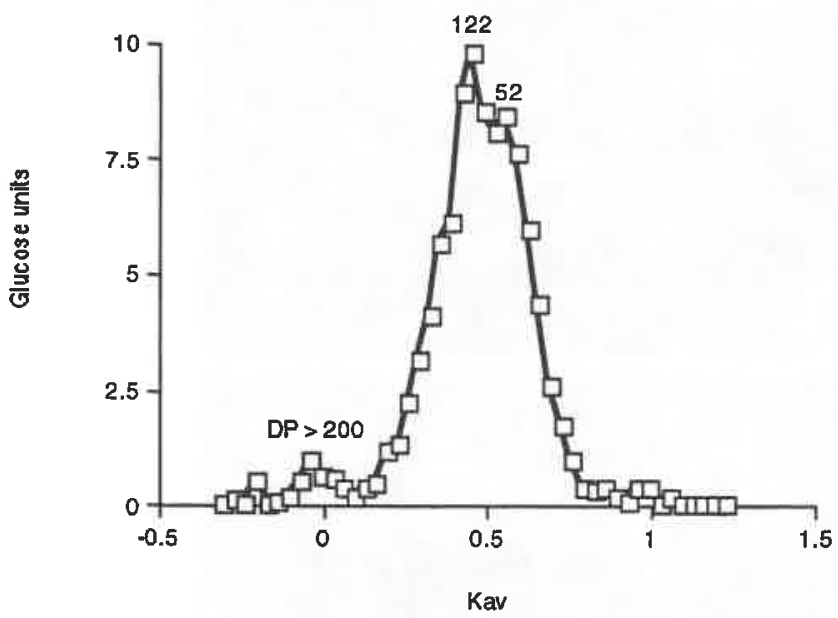

Figure 2. SEC of residues obtained after 24-h $\alpha$-amylolysis with human salivary $\alpha$-amylase and 14 -h washing (related to the amylose DP).

undigested or incompletely degraded starch polymers. The peaks at DP 122 and 52 appeared to represent the limits of $\alpha$-amylolysis after $24 \mathrm{~h}$. The DP 52 oligosaccharides were probably crystalline amylose chains that had retrograded during the long $\alpha$-amylolysis process (Fardet et al., 1998). They probably corresponded to the $7.8 \%$ resistant starch content determined in the protein matrix after washing (Table 1 ). The residual $\alpha$-amylase activity was probably due to strongly adsorbed enzyme macromolecules, which might limit subsequent BSA adsorption onto the protein matrix during the diffusion process.

Heterogeneity in the structure of the protein network, from the outer edge (Figure 3A) toward the center (Figure $3 \mathrm{C}$ ) via the intermediate zone (Figure 3B), resulted from the state of the starch after the lasagne was cooked; that is, the starch granules were less swollen in the center than at the outer edge (Cunin et al., 1995; Fardet et al., 1998). After starch hydrolysis and washing of the protein matrix, the solvent (phosphate buffer) thus replaced the spaces previously occupied by the starch granules, leading to a collapse of the protein matrix, which appeared very dense in the center (Figure 3D) as well as at the outer edge (micrograph not shown).

The method used to prepare the matrix did not allow the protein fraction alone to be isolated from pasta. The result was a heterogeneous, complex system not easily reproducible during each diffusion experiment. Given its porosity (in a range of $\sim 0.5-30 \mu \mathrm{m}$ ) as observed by CLSM (Figure 3D), the lasagne protein matrix was considered as a macroporous system relative to BSA macromolecules having hydrodynamic radii of $\sim 3.1 \mathrm{~nm}$.

Determination of the Protein Matrix Diffusion Coefficient. An example of the increase of BSA mass versus time in the receiver compartment, due to the diffusion of BSA through the protein network of lasagne, is shown in Figure 4. The same plots were obtained for all the experiments summarized in Table 2. Figure 4 shows three zones: a first zone in which BSA quantity in the receiver compartment remained constant and close to zero, which corresponds to BSA diffusion in the protein matrix to reach the boundary in contact with the receiver compartment; a second transition zone in which the $\left(Q_{2}\right)_{\exp }$ versus time plot was not linear, indicating that the concentration of BSA molecules changed through the protein matrix; and a third zone corresponding to the linear variation of the $\left(Q_{2}\right)_{\exp }$ versus time plot and indicating the validity of the Fickian diffusion mechanism through the protein network and the hypothesis of pseudo-steady-state flow after sufficient time has elapsed (see eq 9). The duration of this third zone depends on the variation of the BSA concentrations in the two compartments: as long as $C_{1}$ is constant and $C_{2}$ close to zero, the pseudo-steadystate is justified.

The matrix diffusion coefficient $(D)$ and the partition coefficent $(K)$ were determined simultaneously by minimizing squares of the deviation between the observed $\left(Q_{2}\right)_{\exp }$ and the calculated $\left(Q_{2}\right)_{c a l}$, using eq 6 . The quality of fit between experimental and calculated values is shown in Figure 4 (experiment 1) and was representative of all diffusion experiments (Table 2). As the BSA diffusion process in the protein matrix is very slow, regardless of the BSA concentration in the donor compartment, the diffusion coefficient can be considered as independent of BSA concentration in the first compartment. Moreover, BSA concentrations introduced into the lower compartment at the beginning of diffusion measurements were very low (from $6.25 \times 10^{-5} \mathrm{~g} / \mathrm{L}$ for the lowest to $1.70 \times 10^{-4} \mathrm{~g} / \mathrm{L}$ for the highest). Diffusion processes can therefore be considered to have occurred at infinite dilution. According to these results, all $D$, $K$, and $K D$ values in Table 2 can be used to define their mean and confidence interval (Fisher-Student test with $\alpha=0.95$ ):

$$
\begin{gathered}
D=4.24 \times 10^{-11} \pm 0.31 \times 10^{-11} \mathrm{~m}^{2} / \mathrm{s} \\
K=0.45 \pm 0.04 \\
K D=1.91 \times 10^{-11} \pm 0.14 \times 10^{-11} \mathrm{~m}^{2} / \mathrm{s}
\end{gathered}
$$

The mean and confidence interval for the effective diffusion coefficient $\left(D_{\text {eff }}\right)$ obtained from the slope of the linear part of the $Q_{2}$ versus time plot were (Table 2)

$$
D_{\text {eff }}=1.84 \times 10^{-11} \pm 0.09 \times 10^{-11} \mathrm{~m}^{2} / \mathrm{s}
$$

Interestingly, this value was not significantly different from the value obtained by using the product of $K$ and $D$ (two-coefficient estimation), confirming the equivalence between $D_{\text {eff }}$ and $K D$ in our study.

Determination of Protein Matrix Tortuosity. In a macroporous and inert system, convection movements of the solvent may be the predominant mass transfer mechanism (Langer and Peppas, 1983). Theories of solute diffusion through macroporous matrix assume that solute transport occurs predominantly through the water-filled pores and that this process is slowed (1) by the available pore space for diffusion $(\epsilon)$ and (2) by the geometric characteristics of the path called tortuosity $(\tau)$, the value of which increases with the chaotic nature of the system. These two effects are normally referred to as the exclusion effect and obstruction effect, respectively. 

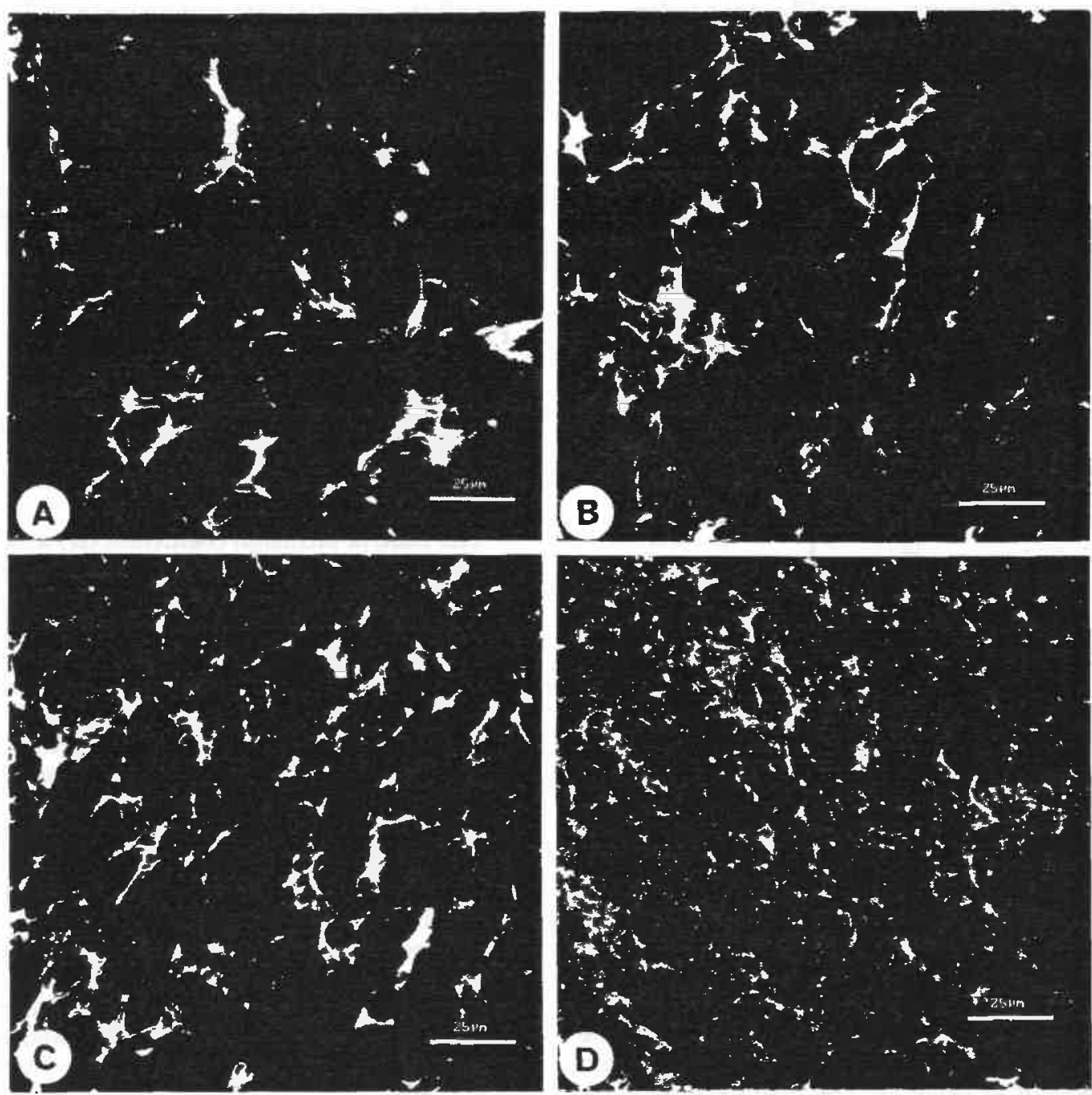

Figure 3. Three-dimensional reconstructed CLSM micrographs of lasagne protein networks before (A-C) and after 24-h $\alpha$-amylolysis and 14-h washing (D). Panels A, B, and C correspond to the external, intermediate, and central zones of the cooked lasagne, respectively. As a result of the false color scale in the images (8-bit grayscale), the pasta protein network appears white in the micrographs.

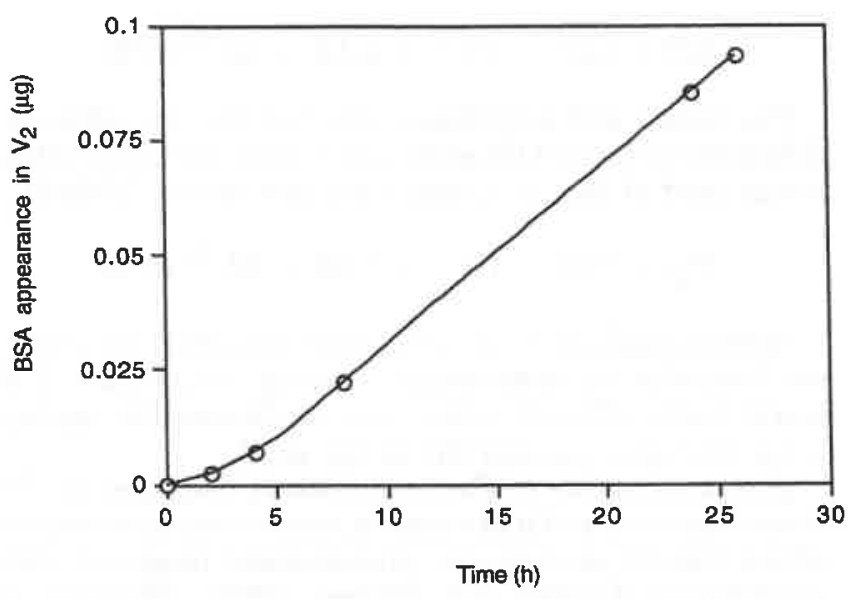

Figure 4. Typical curve for determination of the matrix diffusion coefficient $(D)$ and the partition coefficient $(K)$ obtained from the change of $Q_{t}$ of BSA versus time in the receiver compartment of the steady-state diffusion cell: (solid line) eq 6; (circles) experimental data from experiment 1.

As the apparent thickness of the protein matrix did not change during the diffusion process, tortuosity was considered as constant and was calculated from the following equation, which is well-known from the field of diffusion in porous solids (Epstein, 1989):

$$
\frac{D_{\text {eff }}}{D_{0}}=\frac{K D}{D_{0}}=\frac{\epsilon}{\tau^{2}}
$$

In eq $10, D_{0}$ is the self-diffusion coefficient of BSA at $37^{\circ} \mathrm{C}$ in pure aqueous solution at infinite dilution and $D$ is the BSA diffusion coefficient in the available pore space of the matrix.

$D_{0}$ at $37{ }^{\circ} \mathrm{C}$ was calculated from an experimental value given for BSA at $25^{\circ} \mathrm{C}\left(6.07 \times 10^{-11} \mathrm{~m}^{2} / \mathrm{s}\right.$; Smith, 1970 ) corrected for temperature and water viscosity at $37^{\circ} \mathrm{C}$ (Stokes-Einstein equation). $D_{0}$ was thus equal to $9.29 \times 10^{-11} \mathrm{~m}^{2} / \mathrm{s}$. The mean value of the diffusion coefficient in the protein matrix was assumed to be 4.24 $\times 10^{-11} \mathrm{~m}^{2} / \mathrm{s}$. If we had no adsorption effects of BSA macromolecules onto the protein matrix and if the whole pore network was available for the diffusant, $\epsilon$ could be seen as equal to $K$. Then, from eq 10, the tortuosity of the protein matrix can be calculated

$$
\tau=\sqrt{D_{0} / D}
$$

Its mean and standard deviation were (Table 2)

$$
\tau=1.42 \pm 0.07
$$


Table 2. Values of $D,{ }^{a} K,^{a} K D,{ }^{a} D_{\text {eff, }}^{b}$ and $\tau^{c}$ for Repeated Diffusion Experiments $\left(T=37^{\circ} \mathrm{C} ;\right.$ Stirring $\left.=300 \mathrm{rpm}\right)$

\begin{tabular}{|c|c|c|c|c|c|c|c|c|c|c|c|}
\hline $\begin{array}{l}\text { expt } \\
\text { no. }\end{array}$ & $\begin{array}{l}\text { cell } \\
\text { no. }\end{array}$ & $Q_{1,0}(\mu \mathrm{g})$ & $\begin{array}{l}\text { diffusion } \\
\text { time }(\mathrm{h})\end{array}$ & $V_{1}(\mathrm{~mL})$ & $A\left(\mathrm{~cm}^{2}\right)$ & $L(\mathrm{~mm})$ & $D\left(\times 10^{11} \mathrm{~m}^{2} / \mathrm{s}\right)$ & $K$ & $K D\left(\times 10^{11} \mathrm{~m}^{2} / \mathrm{s}\right)$ & $D_{\text {eff }}\left(\times 10^{11} \mathrm{~m}^{2} / \mathrm{s}\right)$ & $\tau$ \\
\hline 1 & 1 & 2.50 & 26 & 41.0 & 14.28 & 1.50 & 4.04 & 0.50 & 2.02 & 1.91 & 1.45 \\
\hline 2 & 2 & 5.71 & 26 & 37.5 & 9.70 & 1.46 & 4.50 & 0.44 & 1.98 & 1.92 & 1.38 \\
\hline 3 & 1 & 6.78 & 26 & 41.0 & 14.45 & 1.46 & 3.46 & 0.49 & 1.70 & 1.70 & 1.57 \\
\hline 4 & 2 & 4.26 & 26 & 37.5 & 10.04 & 1.48 & 4.41 & 0.38 & 1.68 & 1.81 & 1.39 \\
\hline 5 & 1 & 5.01 & 26 & 41.5 & 15.43 & 1.46 & 4.58 & 0.41 & 1.88 & 1.74 & 1.37 \\
\hline 6 & 2 & 4.52 & 26 & 37.5 & 11.63 & 1.48 & 4.53 & 0.40 & 1.81 & 1.76 & 1,37 \\
\hline 7 & 1 & 6.12 & 26 & 40.5 & 15.90 & 1.50 & 4.18 & 0.49 & 2.05 & 1.86 & 1.43 \\
\hline 8 & 2 & 5.74 & 26 & 37.4 & 11.49 & 1.52 & 4.18 & 0.51 & 2.13 & 2.04 & 1.43 \\
\hline
\end{tabular}

a Obtained by identification from eq 6. ${ }^{b}$ Obtained from the slope of the experimental curve. ${ }^{c}$ Obtained from eq 11.

Table 3. Values of $D,{ }^{a} K,{ }^{a} K D,{ }^{a}$ and $\tau^{c}$ for Repeated Diffusion Experiments in the Presence of a Lipid Complex Emulsion $\left(T=37^{\circ} \mathrm{C}\right.$; Stirring $\left.=300 \mathrm{rpm}\right)$

\begin{tabular}{|c|c|c|c|c|c|c|c|c|c|c|}
\hline $\begin{array}{l}\text { expt } \\
\text { no. }\end{array}$ & $\begin{array}{l}\text { cell } \\
\text { no. }\end{array}$ & $Q_{1,0}(\mu \mathrm{g})$ & $\begin{array}{l}\text { diffusion } \\
\text { time }(\mathrm{h})\end{array}$ & $V_{1}(\mathrm{~mL})$ & $A\left(\mathrm{~cm}^{2}\right)$ & $L(\mathrm{~mm})$ & $D\left(\times 10^{11} \mathrm{~m}^{2} / \mathrm{s}\right)$ & $K$ & $K D\left(\times 10^{11} \mathrm{~m}^{2} / \mathrm{s}\right)$ & $\tau$ \\
\hline 1 & 1 & 5.82 & 28 & 39.1 & 16.85 & 1.40 & 4.24 & 0.37 & 1.57 & 1.48 \\
\hline 2 & 2 & 5.79 & 28 & 37.3 & 11.27 & 1.42 & 4.36 & 0.45 & 1.96 & 1.46 \\
\hline 3 & 1 & 5.61 & 29 & 41.9 & 16.17 & 1.44 & 6.23 & 0.25 & 1.56 & 1.22 \\
\hline 4 & 2 & 5.69 & 29 & 37.4 & 10.38 & 1.44 & 9.88 & 0.21 & 2.07 & 0.97 \\
\hline 5 & 1 & 5.18 & 29 & 41.3 & 15.90 & 1.42 & 6.84 & 0.25 & 1.71 & 1.17 \\
\hline 6 & 2 & 6.09 & 29 & 37.1 & 11.58 & 1.46 & 9.15 & 0.20 & 1.83 & 1.01 \\
\hline
\end{tabular}

${ }^{a}$ Obtained by identification from eq 6. ${ }^{b}$ Obtained from eq 11.

indicating the increase of the pathway during diffusion through the protein matrix (assuming that a value of 1 represents a straight pore). In reality, the BSA diffusing macromolecules were probably too large to enter the whole pore space (as can be seen from the small value of $K$, i.e., 0.45 ). The porosity of the protein matrix can be therefore considered as being larger than 0.45 , and, consequently, the value of the calculated protein matrix tortuosity was underestimated.

Influence of Lipid Complex Emulsion. For six experiments (Table 3), the mean and confidence interval (Fisher-Student test with $\alpha=0.95$ ) of $D, K$, and $K D$ in the presence of lipid complex emulsion were

$$
\begin{gathered}
D=6.78 \times 10^{-11} \pm 1.97 \times 10^{-11} \mathrm{~m}^{2} / \mathrm{s} \\
K=0.29 \pm 0.08 \\
K D=1.79 \times 10^{-11} \pm 0.30 \times 10^{-11} \mathrm{~m}^{2} / \mathrm{s}
\end{gathered}
$$

and $\tau=1.22 \pm 0.22$.

The reason for the increase of $D$ and the decrease of $K$ are not clear at present. When the lipid complex emulsion was introduced in the two compartments of the diffusion cell, the mean value of $D_{\text {eff, }}$ equal to 1.79 $\pm 0.30 \times 10^{-11} \mathrm{~m}^{2} / \mathrm{s}$, was not significantly different from that of $D_{\text {eff }}$ obtained without the lipid emulsion, equal to $1.91 \pm 0.14 \times 10^{-11} \mathrm{~m}^{2} / \mathrm{s}$. However, the value of the partition coefficient decreased, which can be interpreted as a decrease of the available volume for diffusion, that is, a larger exclusion effect. This is compensated by a decreased tortuosity, which increased the matrix diffusion coefficient $(D)$. The tortuous pathway could have been smoothed by the introduction of lipid into the network.

Conclusion. Determination of the BSA diffusion coefficient in the lasagne protein matrix and the use of a diffusional model from the science of porous solids enabled us to quantify tortuosity, a geometric characteristic of the protein matrix. This factor induced a twofold slowing effect of the BSA diffusion coefficient in comparison with diffusion in pure aqueous solvent, indicating that starch accessibility to $\alpha$-amylase in the pasta food structure may be reduced when the protein network is kept intact. At the intestinal level, the rate at which the protein network is hydrolyzed, as compared to starch, is, therefore, an important parameter to consider. Our results also indicate that emulsified lipids, partly representative of the digestive environment, do not limit enzyme diffusion toward and within the pasta protein network.

\section{ABBREVIATIONS USED}

$A$, apparent surface of the protein network $\left(\mathrm{m}^{2}\right)$; BSA, bovine serum albumin; $C$, BSA concentration in the compartment ( $\mu \mathrm{g} / \mathrm{mL})$; CLSM, confocal scanning electron microscopy; $D$, matrix diffusion coefficient $\left(\mathrm{m}^{2} / \mathrm{s}\right)$; $\mathrm{DP}$, degree of polymerization; $D_{\text {eff, effective diffusion }}$ coefficient $\left(\mathrm{m}^{2} / \mathrm{s}\right) ; D_{0}$, self-diffusion coefficient in pure solvent $\left(\mathrm{m}^{2} / \mathrm{s}\right) ; \epsilon$, porosity; $K$, partition coefficient of protein matrix; $K_{\mathrm{av}}$, partition coefficient of SEC column; $L$, thickness of protein matrix diaphragm (m); $N$, number of experimental samples; $Q$, solute quantity in the compartment $(\mu \mathrm{g})$; SEC, size exclusion chromatography; $t$, diffusion time; $V_{1}, V_{2}$, volumes of the lower and upper compartments $(\mathrm{mL}) ; \alpha_{n}$, probability of rejection of a correct value; $\tau$, tortuosity; (subscripts) 0 , initial concentration or quantity; 1 , solute concentration or quantity in the lower compartment (donor); 2, solute concentration or quantity in the upper compartment (receiver).

\section{ACKNOWLEDGMENT}

We gratefully acknowledge the assistance of Brigitte Bouchet and Dr. Paul M. Baldwin (Laboratoire de Biochimie et de Technologie des Glucides, INRA, Nantes) for confocal scanning laser microscopic analyses and three-dimensional reconstructions. This work was presented in part at the Bioavailability '97 Congress (Wageningen, The Netherlands, May 25-28, 1997).

\section{LITERATURE CITED}

Auffret, A.; Barry, J.-L.; Thibault, J.-F. Effect of chemical treatments of sugar beet fibre on their physico-chemical properties and on their in-vitro fermentation. J. Sci. Food Agric. 1993, 61, 195-203. 
Axelsson, A.; Westrin, B. Application of the diffusion cell for the measurement of diffusion in gels. Chem. Eng. Sci. 1991, 46 (3), 913-915.

Buisson, G. D. J.; Duée, E.; Haser, R.; Payan, F. Threedimensional structure of porcine pancreatic $\alpha$-amylase at $2.9 \AA$. Role of calcium in structure and activity. EMBO J. 1987, 6, 3909-3916.

Champ, M.; Noah, L.; Loizeau, G.; Kozlowski, F. Analytical methods of resistant starch. In Proceedings of the AOAC International Workshop: definition and analysis of complex carbohydrates and dietary fiber, Sept 15-16, Nashville, TN; AOAC: Washington, DC, 1995.

Colonna, P.; Barry, J.-L.; Cloarec, D.; Bornet, F.; Gouilloud, S.; Galmiche, J. P. Enzymic susceptibility of starch from pasta. J. Cereal Sci. 1990, 11, 59-70.

Crank, J. The Mathematics of Diffusion, 2nd ed.; Clarendon Press: Oxford, U.K., 1975.

Cunin, C.; Handschin, S.; Walther, P.; Escher, F. Structural changes of starch during cooking of durum wheat pasta. Lebensm.-Wiss. -Technol. 1995, 28, 323-328.

Djelveh, G.; Gros, J. B.; Bories, B. An improvement of the cell diffusion method for the rapid determination of diffusion constants in gels or foods. J. Food Sci. 1989, 54, 166-169.

Epstein, N. On tortuosity and the tortuosity factor in flow and diffusion through porous media. Chem. Eng. Sci. 1989, 44, $777-779$.

Fardet, A.; Guillon, F.; Hoebler, C.; Barry, J.-L. In vitro fermentation of beet fibre and barley bran, of their insoluble residues after digestion and of ileal effluents. J. Sci. Food Agric. 1997, 75, 315-325.

Fardet, A.; Hoebler, C.; Baldwin, P. M.; Bouchet, B.; Gallant, D. J.; Barry, J.-L. Involvement of the protein network in the in vitro degradation of starch from spaghetti and lasagne: a microscopic and enzymatic study. J. Cereal Sci. 1998, 27, 133-145.

Granfeldt, Y.; Björck, I. Glycemic response to starch in pasta: a study of mechanisms of limited enzyme availability. $J$. Cereal Sci. 1991, 14, 47-61.

Guillon, F.; Barry, J.-L.; Thibault, J.-F. Effect of autoclaving sugar-beet fibre on its physico-chemical properties and its in-vitro degradation by human faecal bacteria. J. Sci. Food Agric. 1992, 60, 69-79.

Hoebler, C.; Cherbut, C.; Devaux, M. F.; Lecannu, G.; Malbert, C. H.; Laplace, J. P.; Barry, J.-L. Size of particles of bread and pasta emptied from the stomach of pigs used as human models. In Proceedings of the 7th International Symposium on Digestive Physiology in Pigs; INRA-SRP and EEAP: Saint-Malo, France, May 26-28, 1997.

Ito, K.; Yoshida, K; Okazaki, N.; Kobatashi, S. Effect of processing on the pore size distribution and digestibility of rice grain. Agric. Biol. Chem. 1988, 52, 3001-3007.

Karinthi, A. Dégradations physiques et chimiques subies par des aliments céréaliers au cours des digestions buccales et gastriques. $\mathrm{Ph} . \mathrm{D}$. Dissertation, The Agronomic National Institute of Paris-Grignon (INA-PG), France, 1995.

Keller, K. H.; Canales, E. R.; Yum, S. I. J. Tracer and mutual diffusion coefficients of proteins. J. Phys. Chem. 1971, 75, 379-387.

Langer, R.; Peppas, N. Chemical and physical structure of polymers as carriers for controlled release of bioactive agents: a review. JMS-Rev. Macromol. Chem. Phys. 1983, 23, 61-126.

Leclerc, C.; Champ, M.; Cherbut, C.; Delort-Laval, J. Starch digestion and amylase activity in the small intestine in the presence of guar gums. Sci. Aliment. 1993, 13, 325-332.

Leloup, V. M.; Colonna, P.; Ring, S. G. Studies on probe diffusion and accessibility in amylose gels. Macromolecules 1990, 23, 862-866.

Noah, L.; Guillon, F.; Bouchet, F.; Buléon, A.; Molis, C.; Gratas, M.; Champ, M. Digestion of carbohydrate from white beans (Phaseolus vulgaris L.) in healthy humans. J. Nutr. 1998, $128,977-985$.

Smith, M. H. In Handbook of Biochemistry, 2nd ed.; Sober, H. A., Ed.; Chemical Rubber Co.: Cleveland, OH, 1970; pp C33-C39.

Stokes, R. H. An improved diaphragm-cell for diffusion studies, and some tests of the method. J.Am. Chem. Soc. 1950, 72, $763-767$.

Tanaka, M.; Ikesaka, M.; Matsuno, R. Effect of pore size in substrate and diffusion of enzyme on hydrolysis of cellulosic materials with cellulases. Biotechnol. Bioeng. 1988, 32, 698706.

Thivend, P.; Mercier, C.; Guilbot, A. Determination of starch with glucoamylase. In Methods in Carbohydrate Chemistry; Wistler, R. L., Ed.; Wiley: New York, 1972; pp 100-105.

Tollier, M. T.; Robin, J. P. Adaptation de la méthode à l'orcinol sulfurique au dosage automatique des glucides neutres totaux, conditions d'application aux extraits d'origine végétale. Ann. Technol. Agric. 1979, 28, 1-15.

Wagner, M. L.; Scheraga, H. A. Gouy diffusion studies of bovine serum albumin. J. Phys. Chem. 1956, 60, 1066.

Wong, K. Y.; Deverell, K. F.; Mackie, K. L.; Clark, T. A.; Donaldson, L. A. The relationship between fiber porosity and cellulose digestibility in steam-exploded Pinus radiata. Biotechnol. Bioeng. 1988, 31, 447-456.

Zorrilla, S. E.; Rubiolo, A. C. A model for using the diffusion cell in the determination of multicomponent diffusion coefficients in gels or foods. Chem. Eng. Sci. 1994, 49, 21232128.

Received for review April 13, 1998. Revised manuscript received August 4, 1998. Accepted September 9, 1998.

JF980371N 